\title{
TINGKAT-TINGKATAN BICARA BAHASA BALI (DAMPAK ANGGAH-UNGGUH KRUNA)
}

\section{Nyoman Suwija, I Nyoman Rajeg Mulyawan dan Ida Ayu Iran Adhiti}

Program Studi Pendidikan Bahasa Indonesia dan Daerah, Fakultas Pendidikan Bahasa dan Seni, IKIP PGRI Bali E-mail: inyoman.suwija63@gmail.com

\begin{abstract}
ABSTRAK. Bahasa daerah Bali masih eksis sebagai muatan lokal wajib pada jenjang pendidikan dasar dan menangah.Sistem bicara bahasa Bali yang unik dengan anggah-ungguh basa-nya merupakan warisan budaya Bali yang patut diselamatkan.Mengingat bahasa daerah Bali memiliki peran yang strategis sebagai wahana dan akar budaya Bali, maka bahasa daerah Bali patut dipelihara, dibina, dan dilestarikan. Penelitian ini bertujuan untuk mendeskripsikan tingkat-tingkatan bicara bahasa Bali sebagai dampak dari adanya anggahungguh kruna bahasa Bali.Penelitian ini menggunakan teori sosiolinguistik Fishman (1986). Dalam pengumpulan data digunakan metode observasi dan metode wawancara.Data yang terkumpul dianalisis secara deskriptif analitis. Berdasarkan anggah-ungguh kruna sebagai pembentuknya, tingkatan bahasa Bali dibedakan atas (1) basa kasar (kasar jabag dan kasar pisan, (2) basa andap, (3) basa madia, dan (4) basa alus (alus singgih, alus sor, alus mider).
\end{abstract}

Kata kunci: bicara bahasa Bali; anggah-ungguh basa; sosiolinguistik.

\section{THE LEVELS OF BALINESE SPEAKING (AN IMPACT OF ANGGAH-UNGGUH KRUNA)}

\begin{abstract}
Balinese language still exists as a compulsory local content at the level of primary and secondary education. The unique system of speaking Balinese with anggah-ungguh basa is a Balinese cultural heritage that deserves to be saved. Considering that Balinese has a strategic role as a vehicle and cultural roots of Bali, the Balinese language should be maintained, nurtured and preserved. This study aims to describe the levels of Balinese speaking as an impact of Balinese anggah-ungguh kruna. This study uses sociolinguistic theory Fishman (1986). In collecting data used observation methods and interview method. The collected data was analyzed analytical descriptively. Based on anggah ungguh kruna as its creator, the level of Balinese speaking divided into (1) basa kasar (kasar jabab and kasar pisan), (2) basa andap, (3) basa madia, and (4) bas alus (alus singgih, alus sor, alus mider).
\end{abstract}

Key word: Balinese speaking; anggah-ungguh basa; sociolinguistic.

\section{PENDAHULUAN}

Bahasa Bali merupakan salah satu bahasa daerah yang masih eksis digunakan sebagai alat kumunikasi dalam pergaulan masyarakatnya. Karenanya, bahasa Bali patut dipelihara, dibina, dan dilestarikan. Pemerintah daerah Bali telah memberikan perhatian yang sangat serius terhadap pemertahanan bahasa Bali karena diyakini bahasa Bali merupakan wahana sekaligus akarnya budaya Bali, dimana budaya Bali merupakan tumpuan pariwisata daerah Bali.

Menyadari hal tersebut, ketika mulai berlaku Kurikulum 2013 yang terkesan melemahkan posisi bahasa Bali, Pemerintah Daerah Bali menerbitkan Peraturan Gubernur Bali Nomor 20 Tahun 2013 tentang penegasan Bahasa Daerah Bali sebagai muatan lokal wajib pada jenjang pendidikan dasar dan menengah.

Pada bulan April 2018, terbit lagi Peraturan Daerah Bali No. 1 tentang Pembinaan Bahasa, Aksara, dan Sastra Bali. Hal ini sangat memperkuat status bahasa Bali sebagai bahasa ibu masyarakat suku Bali yang patut dilestarikan. Artinya, sebelum belajar bahasa Indonesia dan atau bahasa asing, anak-anak Bali wajib terlebih dahulu berbahasa Bali sejak lahir di keluarganya masing-masing.

Keterampilan berbicara adalah tujuan akhir yang sangat penting bagi seseorang yang mempelajari bahasa. Hal ini sesuai pendapat Tarigan (1986: 3-4) bahwa berbicara adalah kemampuan seseorang dalam mengucapkan bunyibunyi artikulasi atau kata-kata untuk mengekspresikan buah pikiran, gagasan, dan perasaannya.

Djiwandono (1996: 68) menambahkan bahwa di dalam berbicara seseorang berusaha mengungkap pikiran dan perasaannya kepada orang lain secara lisan. Tanpa berusaha untuk mengungkap dirinya, orang lain tidak akan mengetahui apa yang sedang dipikirkan dan dirasakan. Berbicara merupakan kegiatan berbahasa yang dan memerlukan prakarsa nyata untuk dapat mengungkap diri secara lisan.

Pengertian berbicara terkait penelitian ini adalah berbicara formal yang memenuhi kaidah berbahasa lisan yang baik dan benar. Pada dasarnya setiap orang memiliki keterampilan berbahasa, namun pada saat ditunjuk untuk tampil berbicara pada forum resmi, banyak yang merasa tidak sanggup atau tidak percaya diri. Lebih parah lagi dalam berbahasa Bali karena sistem bicara bahasa Bali termasuk unik, memiliki kosakata kasar-halus yang disebut anggah-ungguhing basa Bali atau tingkat-tingkatan bicara bahasa Bali.

Eksistensi anggah-ungguh basa di dalam bahasa Bali disebabkan oleh adanya pabinayan linggih (perbedaan kedudukan) masyarakat Bali. Keberadaan lapisan masyarakat Bali yang meliputi lapisan masyarakat Bali purwa (tradisional) dan masyarakat Bali anyar (modern), inilah yang menyebabkan sampai sekarang masyarakat 
Bali berbicara sesuai tata linggih yang disebut masor singgih basa atau berbicara sesuai dengan anggah-ungguh basa Bali.

Penelitian ini bertujuan memberikan tingkattingkatan kalimat yang disebut anggah-ungguh basa berdasarkan unsur pembentuknya anggah-ungguh kruna bahasa Bali. Itulah sebabnya penelitian ini menggunakan teori sosiolinguistik Fishman (1986). Menurutnya, sosiolinguistik mengkaji tingkah laku yang meliputi latar, topik, dan fungsi interaksi. Dengan kata lain, kajian sosiolinguistik tidak memfokuskan perhatian pada fenomena kebahasaan saja, tetapi juga memusatkan perhatian pada soal tingkah laku sikap berbahasa, tingkah laku nyata terhadap bahasa dan pemakai bahasa.

\section{METODE}

Dalam penelitian ini digunakan pendekatan deskriptif kualitatif dengan metode studi kasus (Dewi, 2018:192). Pendekatan kualitatifdipandang relevan dengan masalah kebahasaan yang diteliti, yaitu mengeksplorasi dan memahami makna yang oleh sejumlah individu yang dianggap berasal dari masalah sosial kemanusiaan.

Penerapan metode kualitatif sejalan dengan pemikiran Djajasudarma (2009: 10) bahwa metode kualitatif merupakan prosedur yang menghasilkan data secara deskriptif, baik tulis maupun lisan yang berkembang atau berada di masyarakat (dalam Sofyan, 2015: 263).

Sementara itu, metode penelitan studi kasus menurut Creswell (2012: 20) merupakan strategi penelitian dimana peneliti menyelidiki secara cermat suatu program, peristiwa, aktivitas, proses, atau sekelompok individu. Lebih lanjut Sofyan mengatakan bahwa terkait metode ini, data dihasilkan secara deskriptif maksudnya untuk membuat gambaran, lukisan secara sistematis, faktual, dan akurat mengenai data, sifat, serta kaitannya dengan fenomena-fenomena.

Metode deskriptif dilengkapi dengan tiga metode dan teknik, yaitu metode dan teknik pengumpulan data, metode dan teknik analisis data, serta metode dan teknik penyajian hasil analisis data. Pengumpulan data penelitian ini menggunakan metode simak (Sudaryanto (2010: 133). Selanjutnya dalam metode simak digunakan teknik dasar yang meliputi teknik sadap, libat cakap, simak bebas libat cakap, rekam, dan catat (dalam Sofyan: 2015: 263).

Menurut Firdaus (2011: 226), Analisis data menggunakan metode padan, adalah metode yang dipakai untuk mengkaji atau menentukan identitas satuan diagonal dengan memakai alat penentu yang berada di luar bahasa, terlepas dari bahasa yang bersangkutan. Penyajian hasil analisis data menggunakan metode formal dan informal, dibantu dengan teknik induktif dan deduktif.

\section{HASIL DAN PEMBAHASAN}

Kosakata bahasa Bali sebagai unsur pembentuk tuturan yang disebut wacana ada tujuh tingkatan, yaitu:
(1) kruna alus mider yaitu kata-kata halus dwifungsi (bisa digunakan dalam bahasa alus singgih dan alus sor), (2) kruna alus madia yaitu kata-kata halus menengah untuk unsur utama bahasa madia, (3) kruna alus singgih yaitu kata-kata yang memiliki nilai rasa tinggi dan khusus untuk menghormat, (4) kruna alus sor yaitu kata-kata yang memiliki nilai rasa halus untuk merendahkan seseorang yang status sosialnya redahan, (5) kruna andap yaitu kata-kata yang nilai rasanya biasa atau lepas hormat untuk menyebut keadaan orang kebanyakan, (6) kruna mider yaitu kata-kata bahasa Bali yang tidak memiliki bentuk halus, dan (7) kruna kasar yaitu kelompok kata bahasa Bali yang nilai rasanya jelek.

Pada bagian ini akan dibahas tingkat-tingkatan bicara bahasa Bali yang di dalam pelajaran bahasa Bali disebut anggah-ungguh basa Bali. Yang disebut bahasa dalam kajian ini adalah pembicaraan yang dibentuk oleh kumpulan kata-kata yang lebih panjang daripada kalimat. Paling pendek satu paragraf, namun lebih dari satu kalimat sehingga umum disebut wacana, dan kemudian bisa berbentuk satua, makalah, artikel, pidarta, puisi, lagu pop, dialog drama, buku,dan yang lainnya.

Berbicara bahasa Bali sangat tergantung dari partisipannya, siapa berbicara, siapa mitra bicaranya, dan siapa yang dibicarakan. Berdasarkan nilai rasa bahasanya, bahasa Bali dibagi menjadi:(1) basa kasar: a) basa kasar pisan; b) basa kasar jabag; (2) basa andap; (3) basa madia; dan (4) basa alus: a) basa alus singgih, b) basa alus sor, c) basa alus mider, d) basa alus rangkep.

\section{Basa Kasar}

Basa kasar adalah bahasa Bali yang nilai rasanya jelek, sangat tidak sopan, sering dipakai pada saat bertengkar dan mencaci. Basa kasar dipakai berbicara oleh orang yang sedang dalam keadaan resah, gelisah, dan marah. Kadang kala ada masyarakat Bali yang biasa berbicara tidak menghormati orang yang harus dihormati. Harusnya berbicara bahasa halus, namun yang keluar kata-kata yang biasa atau lepas hormat. Senada dengan pendapat di atas, Suwija (2014: 57) mengatakan bahwa yang dimaksud basa kasar adalah sebagai berikut.

Basa kasar inggih punika basa Baliné sané wirasanipun kaon, sering kanggén marebat miwah mamisuh. Basa kasar kanggén mabaos antuk anaké sané ri sedek duka, brangti, wiroda (jengah), miwah kroda (gedeg).

Artinya,

basa kasar yaitu tingkatan bicara bahasa Bali yang mengandung nilai rasa jelek, sering dipakai pada saat berkelahi/bertengkar atau mencaci-maki. Bahasa kasar dipakai berbicara oleh orang yang sedang marah, dengki, jengkel, dan mangkel.

Dalam pembahasan selanjutnya Basa Kasar dibedakan atas (a) Basa Kasar Pisan dan (b) Basa Kasar Jabag. (Suarjana, 2011: 98-100 dan Suwija, 2014: 57-59). 


\subsection{Basa Kasar Pisan}

Basa kasar pisan adalah bahasa Bali yang nilai rasanya benar-benar jelek, bahasa yang sering digunakan pada saat bertengkar atau mencaci-maki. Basa kasar pisan akan keluar dari seseorang sedang marah, resah, dan gelisah. Basa kasar pisan dibentuk oleh kata-kata andap, ditambah kata-kata kasar yang sering digunakan pada saat bertengkar dan mencacimaki.

Yang merupakan tanda atau ciri seseorang mengeluarkan basa kasar pisan adalah penggunaan kanti ganti: Aké, Kai, Cang (Aku) dan Iba, Cicing, Polonibané, Clekotokan ibané (Kamu, Kau), Cicingé totonan, sundelé totonan, ndas keléngé totonan, bangsaté totonan, ndas léaké (Dia).

\section{Contoh basa kasar pisan:}

1. Bahasa seorang perempuan pada wanita lainnya:

Ih cicing, delikang matan ibané! Apa léklék iba mai ah? Awak beduda nagih nandingin geruda. Yen awak beduda, kanggoang tainé urek! Mai Iba nuké anyud, patigrépé. Dasar Iba cicing bengil, pongah ngentut. Kelik-kelik matan Ibané waluya matan buaya, matan sundel. Magedi Iba uli dini! Yen sing nyak magedi, to cicing borosan lakar nyétsét clekotokan Ibané!

Terjemahan:

Ih Anjing, blalakkan matamu! Apa kamu makan ke sini ah? Hah... bagaikan beduda mau menandingi geruda. Kalau dirimu beduda, kanggokan kotoran dinikmati! Kemari Kamu bagaikan tokek hanyut, patigrépé. Dasar Kamu anjing bengil. Tidak tahu malu. Kelik-kelik matamu bagaikan mata buaya, mata si tuna susila. Pergi Kamu dari sini! Kalau tidak mau pergi, itu anjing borosan akan mencobak-cabik tubuhmu!

2. Bahasa Tokoh Punakawan I Joblar pada Raksasa Pertunjukan Wayang Kulit Joblar Lakon Tualen Caru

I Joblar, karena jengkel dan marahnya bukan main terhadap seorang raksasa, dia berbahasa kasar, dipakai mengumpat dan mencaci si raksasa seperti ini.

01. I Joblar: "Wih wih nas liak Iba wih. Ngudiang klianléklékIba? Kadén Iba demen san aké dadi klian? Iba sing mantet busan jumah? Nengéng matan Ibané ked dini?"

02. Raksasa: "Sorry kak Agus Sorry."

03. I Joblar: "Jeneng polon ibané. Kadén iba aluh aké dadi klian?"

04. Raksasa: "Ih marah Kak Agus, kadiang paran?"

05. I Joblar: "Tawang Iba?Yen dadi klian nak cara nyuun bébék muaniné. Boné ngas, tainné liu, munyi dogén, maan sing taluha!
Jeneng Ibané."

Terjemahan:

01. I Joblar: "Wih wih bangsat Kamu wih. Mengapa klian Iba makan? Kamu kira aku suka menjadi klian?Kamu tidak makan tadi di rumah?Memblalakmatamu sampai di sini?"

02. Raksasa: "Sorry kak Agus Sorry."

03. I Joblar: "Aah dasar Kamu. Kamu kira gampang aku menjadi klian?"

04. Raksasa: "Ih marah Kak Agus, kenapa?"

05. I Joblar: "Kamu tahu? Kalau menjadi kelian, seperti memelihara bebekJantan. Bauk, beraknya banyak, suara banyak, tidak dapat telur, Rupamu".

Di sini, I Joblar berbahasa yang kasar pisan pada raksasa. I Joblar berkata begini sebagai contoh bahasa kasar (Wih wih nas liak Iba wih. Ngudiang klian léklék Iba?Iba sing mantet busan jumah? Nengéng Iba ked dini). Tetapi raksasanya malah berbahasa Inggris (Sorry kak Agus Sorry).

Juga ada bahasa Indonesianya (Ih marah Kak Agus), dan bahasa Kawi (Kadiang paran?). I Joblar salanjutnya menggunakan bahasa kasar (Tawang Iba? Yen dadi klian nak cara nyuun bébék muaniné. Boné ngas, tainné liu, munyi dogén, maan sing taluha! Jeneng Ibané, nelik kén Aké).

\subsection{Basa Kasar Jabag}

Basa kasar jabag adalah bahasa Bali yang dibentuk oleh kata-kata andap, juga kadang kala ditambah dengan kata-kata alus madia, tetapi dipakai berbicara dengan orang yang status sosialnya lebih tinggi atau dipakai untuk membicarakan tentang orang yang kastanya lebih tinggi. (Suwija, 2014: 59).

Jadi, bahasa Bali andap yang salah penggunaan itu disebut basa kasar jabag. Seharusnya berbicara halus pada orang yang statusnya lebih tinggi, tetapi keluar kata-kata yang andap. Tentunya hal ini tidak baik. Banyak masyarakat Bali menggunakan bahasa jabag terhadap orang yang status sosialnya lebih tinggi.

Perhatikan contoh basa kasar jabag di bawah!

1) Ih Désak, payu malali bin mani? Yen Désak kal payu milu, ingetang liunang ngaba bekel nah! Saya sing kal ngaba apa. Désak kal cagerang. Yen sak sing ngelah pis, Aku kal meliang malu. Kala ingetang nyen Kamu nguliang nah!

2) Pak Camat, tiang sing nyidang masuk bin mani. Suraté ané baang Bapak ibi suba Luh Rai ngetik. Telung wai tiang izin. Bin petang dina, hari Senin mara men tiang masuk.

Terjemahan:

1) Ih Désak, jadi melancong sekarang? Kalau 
Désak akan ikut, ingatlah banyak bawa bekal ya! Saya tidak akan membawa apa-apa. Desak akan saya handalkan. Kalau Desak tidak punya uang, saya akan membelikan dahulu. Tapi, ingatlah Kamu mengembalikan ya!

2) Pak Camat, saya tidak bisa kerja besok. Surat yang Bapak kasi kemarin sudah diketik oleh Luh Rai. Tiga hari saya izin.Empat hari lagi, hari Senin saya mulau bekerja.

Berbicara dengan Desak, berbicara dengan Pak Camat, berbicara dengan Cokorda wajib hukumnya menggunakan bahasa yang halus (menghormat). Kalau seseorang salah menggunakan basa andap, pada hal seharusnya berbahasa halus, akhirnya keluar bahasa andap, inilah yang disebut berbahasa kasar jabag.

Contoh bahasa kasar jabag lainnya:

01. Maruti: "Pejah kita mangké."

02. Tualén: "Matiang Tu tiang mangkin?"

03. Maruti: "Yogya."

04. Tualen: "Yen ba tiang matiang Atu kal éngkén bana guminé? Atuten bisabalas budi. Ingetang ja anakétiang, ampunang tiang matianga! Ten Atu éling? Dugas Pemiluné kadén tiang ané milih Tu? Miratdana Atu."

Terjemahan:

01. Maruti: "Mampus Kamu sekarang."

02. Tualén: "Anda bunuh saya sekarang?"

03. Maruti: "Iya, benar."

04. Tualen: "Kalau saya sudah mati, bagaimana negeri ini? Anda tidak bisabalas budi. Ingatlah jasa saya.Anda tidak ingat? Saat pemilu kan saya yang membantu Anda?

Dalam dialog di atas, tokoh Tualén sebagai bawahan, menggunakan bahasa jabag berbicara dengan atasannya/ junjungannya Sang Anoman (Maruti). Seharusnya I Tualen berbicara menggunakan bahasa halus, ia banyak menggunakan kata-kata andap. Itu sebabnya kata-kata I Tualen termasuk jenis basa kasar jabag.

\section{Basa Andap}

Istilah basa andap dikemukakan oleh Suarjana (2011: 101). Kruna andap berarti éndép (rendah). Hal itu ditegaskan, dipakai membedakan dengan bahasa kasar (jelek) Dahulu bahasa yang biasa juga termasuk katagori kasar. Bahasa andap yang nilai rasanya rendah itu, berbeda dengan bahasa yang kasar. Basa andap tersebut, yang dirasakan andap/éndép (rendah) adalah nilai rasanya.

Dengan dasar pemikiran seperti itu, dapat dijelaskan bahwa bahasa andap adalah bahasa Bali yang memiliki makna biasa, tidak kasar, tidak menengah, dan tidak halus. Bahasa andap itu dipakai berbicara oleh orang yang derajatnya sama atau sederajat (sesamén wangsa), juga dipakai oleh orang yang status sosialnya lebih tinggi dengan orang yang status sosialnya lebih rendah.

Contoh bahasa andap:

1) Bahasa I Wayan Duria terhadap pacarnya, Luh Sunari

"Luh ... Luh Sunari. Tegarang ja tolih i padang! Liglig ia kameranan, angajap-ajap kritisan ujan ané marupa tresnan Luhé. Bedak layah ia ngulatiang sukalegan idep Luhé, apanga sida enu maurip di guminé. Tan péndah ia i tuké anyud, patigrépé ngalih paenjekan. Tulya i tabia dakep ané nyaratang tungguhan, apang enu idup di guminé”.

Terjemahan:

"Luh ... Luh Sunari. Cobalah lihat si rumput! Liglig dia melarat, berharap banyak rintikan air hujan yang berupa cinta Kamu. Haus lapar ia mengharapkan keikhlasan hati Kamu, supaya dia masih bisa hidup di jagat ini. Tak obahnya dia si tokek hanyut, patigrépé mencari sandaran. Bagaikan si cabai rambat mencari sandaran, supa bisa bertahan hidup"

2) Bahasa Raja terhadap Punakawan

Nah Paman, para patih, tandamantri, kéto masi CaiNyai panjak gelahé ajak makejang. Sangkal ké ada gelah sarat madedauhan, mapangedih apang paman muah para panjaké makejang sida parek tangkil buka jani. Mula ada ané saratang gelah, ada ané mabuat lakar raosang gelah kapin paman ajak makejang. Né mapan gelah suba madan lingsir. Ada lantasan Gustin pamané, buka ia putran gelah I Cening Bagus Jayaningrat ané suba suud nunas ajah ring Ida Hyang Bhagawan. Suba mirib panemaya gelah nyerahang kaprabon tekén $i$ cening bagus. To jani ané patut raosang! ...

Terjemahan:

Baiklah Paman, para patih, tandamantri, demikian juga rakyatku sekalian. Adanya saya memberitahukan, meminta supaya paman dan rakyat semua biusa menghadap pada hari ini. Memang ada yang saya pentingkan, ada yang mendesak patut dibicarakan pada kalian semua. Ini karena saya sudah berusia tua, ada junjungan kalian dia anakku Si Bagus Jayaningrat yang sudah usai menimba ilmu pada Ida Hyang Bhagawan. Sudah waktunya saya menyerahkan tahta kerajaan pada dia. Itu;lah sekarang yang patut dibicarakan! . . .

\section{Basa Madia}

Suwija (2014: 60) mengatakan bahwa basa madia adalah bahasa Bali yang kelihatan/kedengaran seperti bahasa halus, tetapi makna dan nilai rasanya masih menengah (madia) karena banyak dibentuk oleh katakata halus madia. 
Suarjana (2011: 103) mengatakan bahwa dalam praktiknya basa madia tidaklah terlalu hormat dan biasanya ditandai dengan pemakaian kata-kata madia, membentuk kalimat madia, dan akhirnya membentuk basa madia. Bahasa madia banyak sekali ditemukandalam komunikasi pergaulan di masyarakat. Seharusnya mengucapkan sampun, diucapkan ampun, seharusnya mengucapkan inggih diucapkan $\boldsymbol{n g g i \boldsymbol { h }}$, seharus mengucapkan nénten diucapkan ten, dan selanjutnya. Selain itu, bahasa madia ini sering digunakan berkomunikasi oleh masyarakat Bali yang belum saling kenal, yang sering menyebutkan matiang - jero. Perhatikan contoh basa madia berikut.

\section{1) Tekslagu pop Bali Rajapala}

\section{RAJA PALA}

Aduh, kadi pituduhing Widhi wiakti, Ageté dong ja dadi uber, lacuré dong ja dadi kelidin.

I Raja Pala, juru boros katempuh liang, peluhnyané ngucur, nguber kedis, ngojog anak manjus. Widiadari Kén Sulasih, jegég, ayu, putih, mulus, tan pasanding.

Jero-jero ... anak lanang bagus genjing, wantah titing widiadari, Kén Sulasih parab titiang.

Napi wénten ... ngambil busanan titiangé, titiang nyadia mangentosin, antuk jinah mas tur mirah. Aduh, anggon tiang napi mas pipis di alasé?

Matumbasan sing ada dagang, bungah tiang nganggo, sing ada nak nepukin.

Rajapala parab titiang truna lara, yéning suéca pakayunan makaronan,

Ratu ayu sareng titiang truna lara. Aduh, beli beli Raja Pala.

Duaning kapelek rasa manah tiangé, Misadia tiang nagingin pangedih beliné.

Sakewala, ada, ada idih tiang kén beli. Mangkin wénten ...

pinunas titiang ring beli, yéning wénten putra adiri, titing mapamit ring beli.

Kalau didengar sekilas, Lagu Pop Bali "Raja Pala" sepertinya menggunakan bahasa Bali halus. Tetapi kalau diperhatikan, banyak sekali menggunakan katakata basa andap. Hal ini menyebabkan bahasanya termasuk basa madia. Juga seperti ciri bahasa madia tetapi keduanya(Bidadari Kén Sulasih dan si pemburu, I Rajapala) belum saling mengenal. Harusnya pada saat berkomunikasi keduanya menggunakan bahasa madia atau "matiang-jero".

Seperti itulah keberadaan bahasa Bali yang dipakai membentuk lagu di atas, kata-katanya bercampur menggunakan kruna mider, kruna andap, dan kruna alus. Bahasa lagu sebagai konsumsi publik hendaknya menggunakan bahasa yang baik dan benar. Lirik lagulagu pop Balisangat baik sebagai sarana mempelajari tingkat-tingkatan bahasa Bali olehanak-anak, siswa, generasi muda, dan oleh masyarakat seluruhnya.Kalau bahasa lagu banyak mengandung kesalahan, akan berdampak negatif terhadap pemertahanan bahasa daerah Bali,karena anak-anak terbiasa mendengar bahasa yang salah.

\section{2) Pakenalan Ketua OSIS}

Padaacara MOS siswa Kelas VIIbaru,sebelum acara dilanjutkan, ada Ketua OSIS memperkenalkan diri dengan para peserta MOS.Begini katanya.

01. Ketua OSIS: "Inggih para sameton OSIS pamekas sané wawu kelas VII (pitu). Sadurung matur, titiang jagi nyinahang déwék riin nggih? Titiang mawasta I Madé Lara.

02. I Putra): "Napi mawinan mawasta Lara?"

03. Ketua OSIS: "Duaning daweg tiangé embas, mémén tiangé gelem keras tur ngraris padem".

04. Luh Rai: “O... Dadosné kak Lara anak yatim nggih?"

05. Ketua OSIS: "Nggih, tiang anak ubuh".

06. Luh Rai: "Tamat SD napi dumun Kak?"

07. Ketua OSIS: "Tiang tamatan SD Dwijéndra Denpasar"

08. Luh Rai: “O... kénten? Taén ajina kén ibuk tiangé?"

09. Ketua OSIS: "Yé... Sira peséngané?"

10. Luh Rai: "Ibuk Purnama Sari"

11. Ketua OSIS: "O... nggih. Daweg Kelas IV tiang ajahina".

Terjemahan:

01. Ketua OSIS: "Baiklah teman-teman OSIS, utamanya yang baru kelas 7 , sebelum berbicara, saya akan memperkenalkan diri dahulu ya? Saya bernama I Made Lara.

02. I Putra): "Apa sebabnya bernama I Lara?"

03. Ketua OSIS: “Karena pada saat saya lahir, ibu saya sakit keras, dan lanjut meninggal".

04. Luh Rai: “O... Jadi, Kak Lara anak yatim ya?”

05. Ketua OSIS: "Ya, saya anak yatim".

06. Luh Rai: "Tamat SD mana dulu, Kak?"

07. Ketua OSIS: "Saya lulusan SD Dwijéndra Denpasar"

08. Luh Rai: "O... begitu? Pernah diajar oleh ibu saya?"

09. Ketua OSIS: "Yé... Siapa namanya?"

10. Luh Rai: "Ibuk Purnama Sari"

11. Ketua OSIS: "O... ya. Saat Kelas IV saya diajarnya".

\section{Basa Alus}

Bahasa halus merupakan tingkatan bahasa Bali yang tinggi atau sangat hormat dan biasanya bahasa tingkatan ini digunakan dalam situasi resmi (Suarjana, 2011: 105). Bahasa alus sangat umum dipakai menghormati orang yang status sosialnya lebih tinggi atau merendahkan orang yang status sosialnya lebih rendah. Bahasa halus 
hanya digunakan oleh orang yang status sosialnya lebih rendah pada saat berbicara dengan terhormat, juga pada saat merendahkan diri atau orang lain.

Jadi, sesusai dengan etika berbicara bahasa Bali, bahasa halus digunakan berkomunikasi oleh orang golongan bawah (sang sor) terhadap dan tentang golongan atas (sang singgih) atau orang yang dihormati, seperti: (1) Bahasa punakawan pada raja, (2) Bahasa atur murid pada guru, (3) Bahasa atur pegawé pada pejabat, (4) Bahasa atur Dé Rai pada Limbur/Liku, (5)Bahasa atur mahasiswa pada dosén.

\subsection{Basa Alus Singgih}

Basa alus singgih adalah bahasa Bali yang maknanya halus serta dipakai menghormati orang yang derajatnya lebih tinggi. Baikorang yang derajatnya lebih tinggi yang diajak berbicara atau orang yang dibicarakan, patut dihormati, menggunakan kata-kata alus singgih.

Masyarakat wangsa jaba (orang kebanyakan) yang berbicara dengan orang tri wangsa atau membicara tentang tri wangsa harus menggunakan bahasa alus singgih. Umpama, Tokoh I Tualén pada saat berbicara dengan junjungannya, Sang Ramadéwa, membicarakan tentang keadaan dirinya, I Tualén harus menggunakan bahasa alus sor. Apabila ada seorang siswa, berbicara dengan bapak/ibu guru, siswa itu juga harus menggunakan bahasa alus singgih. Perhatikan contoh berikut.

1) Bahasa Punakawan terhadap Raja

Ratu déwa agung, dados makadi pranagata, nadak sara cokoridéwa ngeséngin sikian titiang, mangda titiang pedek tangkil rahinané mangkin. Samaliha sapamedal cokoridéwa makanten ucem remrem tatwadana druéné, tan péndah kadi sekar pucuké kaulet. Napi manawi wénten sané sungsutang cokoridéwa? Inggih durus-durus cokoridéwa mawecana, mabaos ring parapanjaké sami!

Terjemahan:

Ratu déwa agung, mengapa demikian mendadak Tuanku memanggil kami supaya bisa menghadap hari ini? Lagipula keluarnya Tuanku terlihat demikian pucat wajah Tuanku tak obahnya bagai bunga kembang sepatut diremas. Apa gerangan yang membuat Tuan bersedih? Ayolah berbicara Tuanku. Sampaikan saja pada kita semua!

2) Bahasa Pegawai Membicarakan Bapak Réktor Titiang sampun polih tangkil ring Bapak Réktor duk Saniscara lintang. Dané sampun nerima rerepi saking panitia. Nanging duaning dane jagi lunga ka Jakarta rahina bénjang, indik pangrencana lokakarya punika durung prasida kacumponin. Dané maosang sarauhé saking Jakarta pacang ngwéntenang paruman alit kanggén galah mligbagang indik prabéa sané patut baosang.

Terjemahan:

Saya sudah sempat menghadap Bapak Rektor pada hari Sabtu yang lalu. Beliau sudah menerima surat dari panitia. Namun, karena beliau akan berangkat ke Jakarta besok, tentang perencanaan lokakarya tersebut belum mendapatkan persetujuan. Beliau mengatakan setiba dari Jakarta akan menggelar rapat kecil dipakai membahas tentang dana yang perlu dibicarakan.

\subsection{Basa Alus Sor}

Basa alus soradalah segala bentuk komunikasi berbahasa Bali yang maknanya halus, dipakai untuk merendahkan diri atau merendahkan orang yang derajatnya lebih rendah yang harus direndahkan. Siapa saja yang sedang berbicara di dalam forum resmi diwajibkan merendahkan diri menggunakan bahasa alus sor.

Contoh bahasa alus sor seperti di bawah ini.

1) Pak Suwija memperkenalkan diri

Idadanésanéwangiangtitiang, sadurung nglantur matur, lugrayang riin titiang nyinahang déwék. Mungguing wastan titiang, I Nyoman Suwija. Titiang wit saking Désa Sobangan, Kecamatan Mangwi, Kabupatén Badung. Sarahina-rahina titiang makarya ringProdi Pendidikan Bahasa dan Sastra Bali, Fakultas Pendidikan Bahasa Indonesia dan Daerah, IKIP PGRI Bali. Titiang sampun makulawarga, maderbépianak tigang diri. Mangkin, titiang jenek ring Jl. Antasura, Gang Batusari Timur, No. 26 Denpasar Utara.

\section{Terjemahan:}

Hadurun yang saya hormati, sebelum melanjutkan berbicara, izinkan terlebih dahulu saya memperkenalkan diri. Nama saya I Nyoman Suwija. Saya berasal dari Désa Sobangan, Kecamatan Mangwi, Kabupatén Badung. Sehari-hari saya bekerja di Prodi Pendidikan Bahasa dan Sastra Bali, Fakultas Pendidikan Bahasa Indonesia dan Daerah, IKIP PGRI Bali. Saya sudah berkeluarga, punya tiga orang anak. Sekarang saya tinggal di Jl. Antasura, Gang Batusari Timur, No. 26 Denpasar Utara.

Pada contoh di atas, saya (I Nyoman Suwija) berbicara dengan orang yang banyak, seperti peserta tuntunan berbicara bahasa Bali alus. Saya merendahkan diri dengan menggunakan bahasa alus sor. Saya tidak memperkenalkan diri mapeséngan, tetapi mawasta. Juga tidak menyebut angga, tetapi déwék.Juga tidak 
menyebut madué rabi, tetapi madérbé kurenan. Juga tidak benar menyebutkan madué oka, tetapi kabaos madérbé pianak. msl.

2) Bahasa Luh Rai pada Bapak Bupati

Palungguh Bupati sané singgihin titiang, Titiang nunas ampura ping banget pisan, riantuk rahinané mangkin titiang nénten prasida nyarengin pidabdab lomba nyastra Bali sané kalaksanayang ring Wantilan Pura Lingga Bhuwana Puspem Badung. Titiang maderbé alangan sané nénten prasida katinggalin, bapak titiangé sedek sinengkaon rahat ring Rumah Sakit Sanglah. Indik rerepi sané ketik titiang dibi sampun puput saha magenah ring méjan Bapak.

Terjemahan:

Bapak Bupati yang saya hormati, saya minta maaf yang sebesar-besarnya karena hari ini saya tidak bisa mengikuti kegiatan lomba nyastra Bali yang dilaksanakan di Wantilan Pura Lingga Bhuwana Puspem Badung. Saya punya halangan yang tidak dapat ditinggalkan, bapak saya sedang sakit keras di Rumah Sakit Sanglah. Tentang surat yang saya ketik kemarin sudah selesai dan ditaruh di atas meja Bapak.

\subsection{Basa Alus Mider}

Basa alus mider adalah tingkatan bicara bahasa Bali yang bermakna halus, sering dipakai berbicara dalam rapat, berbicara pada orang banyak. Komunikasi itu terkait dengan orang yang berbicara atau orang yang diajak berbicara. Kata ganti yang digunakan pada umumnya adalah kata saya (tiang) atau kata dia (jero).

A. Contoh bahasa alus mider 1

Ida dané krama banjar sané wangiang titiang, duaning sampun panemaya, ngiring mangkin kawitin paruman druéné. Sadéréng nglantur, ngiring ngastiti bakti ring Ida Hyang Widhi, mangda asung ngicénin iraga karahajengan, gumantiné punapa-punapi sané jagi kabaosang malih ajebos sidaning don labdakarya. Ngiring nyakupang kara kalih, nguncarang pangastungkara, Om Swastyastu.

Terjemahan:

Saudara-saudara krama banjar yang saya hormati, karena sudah waktunya, mari kita mulai rapat ini. Sebelum lanjut, mari bersama-sama menghaturkan puja pangastuti kepada Tuhan Yang Maha Esa, supaya berkenan memberikan sinar sucinya untuk keselamatan, sehingga apa pun yang akan dibicarakan nanti berhasil guna sesuai harapan. Mari mengambil sikap amustikarana mengucapkan salam umat, Om Swastyastu.
Contoh bahasa di atas adalah kata-kata Kelian dengan warga banjar serta mengajak atau mengikuti warga banjar membuka atau memulai rapat dengan mengucapkan panganjali umat. Orang yang berbicara (kelihan)mengajak warga banjar akan melaksanakan pekerjaan, memulai rapat. Jadi kata-kata itu bersama-sama digunakan oleh orang yang berbicara dengan orang yang diajak berbicara sehingga bahasanya itu disebut bahasa alus mider.

B) Contoh bahasa alus mider 2

Inggih, Ida dané krama banjar sané wangiang titiang, duaning sampun akéh piragin titiang wénten usul $i$ wawu, mangkin ngiring sarengsareng mikayunin, sané encen minab jagi kacumponin? Ida dané mangkin tunasin titiang pamutus baos. Ngiring medalang malih pikayunan druéné gumanti wénten pacumponan anggén gegamelan nglanturang pawangunan balé banjar druéné.

Terjemahan:

Baiklah, Saudara krama banjar yang saya hormati, karena sudah banyak saya dengar ada usul dan saran, sekarang mari bersama-sama dipikirkan, yang mana kira-kira patut disetujui? Saudaralah yang sekarang saya mintai pendapat. Mari keluarkan pemikirannya supaya ada keputusan dipakai pedoman melanjutkan pembangunan bale banjar kita.

Contoh komunikasi ini juga kata dari kelian bajnar dengan warga banjarnya mengajak masyarakat mengeluarkan pendapat menyetujui supaya menghasilkan keputusan atau rapat akan dipakai pedoman melanjutkan pembangunan. Komunikasi ini juga komunikasi bersamaan oleh orang yang berbicara dengan orang yang diajak berbicara, sehingga disebut bahasa alus mider.

\section{SIMPULAN}

Bahasa Bali dikenal rumit dan unik karena sistem bicaranya tergantung dari adanya kosakata yang memiliki bentuk kasar-halus yang disebut sor-singgih atau anggahungguh basa. Sebagai dampak dari unsur pembentuknya yaitu kata-kata yang memiliki anggah-ungguh kruna atau tingkat-tingkatan kata, tingkatan bicara bahasa Bali dibedakan atas: (1) bahasa kasar (bahasa kasar pisan dan bahasa kasar jabag); (2) bahasa andap; (3) bahasa madia; dan (4) bahasa alus (bahasa alus singgih, alus sor, dan alus mider).

Berdasarkan hasil pengamatan, tidak akan mungkin sebuah tingkatan bahasa dibentuk oleh kata-kata yang nilai rasanya sama. Pemunculan tingkatan kata sebagai unsur pembentuk tuturan berbentuk wacanaakan saling melengkapi. Artinya, bahasa alus singgih tidak mungkin 
semua kata pembentuknya kata-kata alus singgih; bahasa alus sor, tidak mungkin pula semua kata pembentuknya memiliki nilai rasa alus sor, demikian seterusnya. Selanjutnya, jika dicermati lebih saksama, tingkatan bicara bahasa Bali sangat tergantung dari partisipannya. Artinya, sangat tergantung pada siapa yang berbicara, siapa mitra bicaranya, dan siapa yang dibicarakan.

\section{DAFTAR PUSTAKA}

Creswell, J.W. (2012) Research Desain: Pendekatan Kualitatif, Kuantitatif, dan Mixed. Yogyakarta: Pustaka Pelajar.

Dewi, E.A.S. \& Pratamawati, B.B. (2018). Komunikasi Politik Pemerintah Kabupaten Bandung Barat dalam Menyosialisasikan Masyarakat Ekonomi ASEAN (MEA). Sosiohumaniora, 20, (2), 188198.

Djajasudarma, T.F., (2009). Analisis Bahasa Sintaksis dan Semantik. Bandung: Uvula Press Fakultas Sastra Universitas Padjadjaran.

Firdaus, W. (2011) Kata-Kata Serapan Bahasa Aceh dari Bahasa Arab: Analisis Morfofonemis, Sosiohumaniora, 13, (2), 223-234.

Sofyan, A.N. (2015) Frasa Direktif yang Berunsur Di, Dari, dan Untuk dalam Bahasa Indonesia: Kajian
Sintaktis dan Semantis, Sosiohumaniora. 18, (3), 262-267.

Suarjana, I.N.P. (2011). Sor Singgih Basa Bali: Kebalian Manusia Bali dalam Dharma Pepadikan, Pidarta, Sambrama Wacana, dan Dharma Wcana. Denpasar: Tohpati Grafika Utama.

Sudaryanto, (2012). Metode Linguistik: Kedudukan, Aneka Isinya, dan Faktor Penentu Wujudnya. Yogyakarta: Fak. Sastra dan Kebudayaan, Universitas Gajah Mada.

Suwija, I. N., (2014). Tata Titi Basa Bali. Dénpasar: Pelawa Sari.

Suwija, I.N., (2017). Identification of Anggah-Ungguh Kruna in Balinese Language, International Journal of Linguistics, Literature, and Culture. (IJLLC). 3, (6), 12-18.

Suwija, I.N., (2018). Sistem Sapaan Bahasa Bali menurut Hubungan Kekrabatan, Sosiohumaniora. 20, (2), 115-121.

Suwija, I.N., (2018). Role of Anggah-Ungguh Kruna in Balinese Language Sentence Formation International Journal of Social Sciences and Humanities. (IJSSH), Vol. 2 No. 3. 21-32. 